\title{
Cultural Guidelines for Commercial Production of Interiorscape Syngonium ${ }^{1}$
}

\author{
Jianjun Chen, Dennis B. McConnell, and Kelly C. Everitt ${ }^{2}$
}

\section{Introduction}

Syngonium is a perennial, evergreen, herbaceous vine of the family Araceae. Linneaus originally classified Syngonium sp. as Arum auritum in 1763. Schott changed the name to its modern genera in 1829. Thirty three species are recognized and all are hemiepiphytic and native to moist, elevated forests of Mexico, Panama, El Salvador, Guatemala, Brazil, and Honduras.

Syngonium podophyllum, also known as arrowhead plant, nephthytis, African evergreen, and goosefoot plant, is the most commonly produced species in the foliage plant industry. It is recognized by its juvenile leaves, which are simple, alternately arranged, saggitate to hastate in shape, approximately 3-7 inches $(7.5-17.5 \mathrm{~cm})$ long and somewhat velvety. The common name, arrowhead plant, reflects the botanical leaf description. Mature leaves are dramatically different: they are compound with 3-11 elliptic leaflets, and the center leaflet may attain a length of 1 foot $(19 \mathrm{~cm})$ with a 2 -foot $(38 \mathrm{~cm})$ petiole. The shape and color of the juvenile leaves is frequently used to name the cultivars that are commercially available. In most environments, each node sports adventitious roots. Flowers are a typical aroid spathe and spadix, white or cream colored with red or violet highlights, and are unremarkable.

This article is intended to describe common cultivars in the foliage plant industry, provide guidelines for their culture and interior use, and list physiological problems that may be encountered during production and interiorscape use.

\section{Cultivars}

See Table 1.

\section{Cultural Guides \\ Propagation}

Syngonium propagation is easily done via nodal cutting, tip cuttings or air layers. The simplest method is to cut sections of the vine into single node or single eye (a single node with an attached leaf and adventitious roots) and place it directly into a rooting medium under mist. Air temperatures between 75 and $95^{\circ} \mathrm{F}$ are recommended with bottom heating

1. This document is ENH 993, one of a series of the Environmental Horticulture Department, Florida Cooperative Extension Service, Institute of Food and Agricultural Sciences, University of Florida. Original publication date April 2005. Please visit the EDIS web site at http://edis.ifas.ufl.edu.

2. Jianjun Chen, Associate Professor, Mid-Florida Research and Education Center and Environmental Horticultural Department, Dennis B. McConnell, Professor, Environmental Horticultural Department, and Kelly C. Everitt, Research Assistant, Mid-Florida Research and Education Center at the Institute of Food and Agricultural Sciences, University of Florida.

The Institute of Food and Agricultural Sciences (IFAS) is an Equal Opportunity Institution authorized to provide research, educational information and other services only to individuals and institutions that function with non-discrimination with respect to race, creed, color, religion, age, disability, sex, sexual orientation, marital status, national origin, political opinions or affiliations. U.S. Department of Agriculture, Cooperative Extension Service, University of Florida, IFAS, Florida A. \& M. University Cooperative Extension Program, and Boards of County Commissioners Cooperating. Larry Arrington, Dean 
beneficial if the root zone is kept between 70 and $75^{\circ} \mathrm{F}$. Shade of $80 \%$ ( $2500 \mathrm{fc}$ ) is required for rooting. Some cultivars are propagated by seed. However, almost all commercial production has shifted to tissue culture liners.

\section{Production}

Liners, rooted cuttings, or seedlings are transplanted in 4-, 6-, or 8-inch pots and grown in shadehouses or shaded greenhouses. Commercial media formulated by combination of peat, pine bark, vermiculate, and/or perlite with $\mathrm{pH}$ of 5.5 to 6.5 and soluble salts of 1 to $2 \mathrm{dS} / \mathrm{m}$ are suitable for Syngonium production. Plants should be grown under $80 \%$ shade, in relative humidity of 60 to $100 \%$, and in temperatures between 70 and $90^{\circ} \mathrm{F}$. If plants are fertigated via drip or ebb-and-flow irrigation, a nutrient solution with $\mathrm{N}$ at $150 \mathrm{ppm}$ can be used. This solution can be made using a water-soluble fertilizer with $\mathrm{N}-\mathrm{P}_{2} \mathrm{O}_{5}-\mathrm{K}_{2} \mathrm{O}$ at a 3-1-2 ratio, such as a 24-8-16 or 18-6-12 with micronutrients. If a controlled-release fertilizer with the $\mathrm{N}-\mathrm{P}_{2} \mathrm{O}_{5}-\mathrm{K}_{2} \mathrm{O}$ ratio of 3-1-2 is used, apply it at rate of $6.5 \mathrm{lb} \mathrm{N}$ per 1,000 square feet on a quarterly basis or $26 \mathrm{lbs}$ N/1000 sq. ft annually. Potting media should be kept moist but not wet when controlled-release fertilizers are used in production. Growers are strongly recommended to monitor the nutrient status of potting media by checking soluble salts levels biweekly using an electrical conductivity (EC) meter. Media solution can easily be extracted using the pour-through method. If EC readings fall below 1.0 $\mathrm{dS} / \mathrm{m}$, additional fertilization is needed; whereas if EC readings are above $3.0 \mathrm{dS} / \mathrm{m}$, growers should reduce either the frequency or amount of applied fertilizer. It is recommended that fertilizer applications be reduced or eliminated one month before plants are shipped. Table 2 provides a general guide for determining if Syngonium is appropriately fertilized based on leaf analysis.

See Table 2.

\section{Shipping and Interior Care}

Shipping sleeves are recommended for transporting finished Syngonium. Recommended temperature range for shipping is 55 to $60^{\circ} \mathrm{F}$ as exposure to a temperature below $55^{\circ} \mathrm{F}$ may cause chilling injury. Irrigate the media thoroughly the day before shipping to reduce stress during transportation.

Syngonium is commonly used as hanging baskets. If upright growth is desired, a totem, trellis, or other support is needed. Otherwise, plants can be used for ground cover. Optimal light levels for Syngonium in interiorscapes range from 250 to 1000 $\mathrm{ft}$, and plants maintain their aesthetic appearance better if relative humidity is maintained between 40 and $60 \%$. Allow the surface of potting media to dry slightly before irrigating. During the winter, reduce watering frequencies but do not allow the plant to dry out. Temperatures should remain between 65 and $80^{\circ} \mathrm{F}$ to maintain leaf colorings. Occasional pruning is necessary to maintain plant form, and misting with water and wiping the leaves with a lint-free cloth will keep plants dust free and reduce the probability of a pest infestation.

\section{Pest Problems}

Although aphids, spidermites, scale, and mealybug infestations occur, they are relativity rare if the relative humidity is properly maintained. Snails, slugs, thrips, and whitefly infestations have also been reported but usually occur when plants are maintained in ground beds with minimal care. Most diseases that infect Syngonium occur during production. These include Erwinia, Pseudomonas, Xanthomonas, Myrothecium, Rhizoctonia blight, and Cephalosporium.

\section{Physiological Problems}

See Table 3. 
Table 1. listing of most of the cultivars available in Florida as of 2004.

\begin{tabular}{|c|c|}
\hline Cultivar & Characteristics \\
\hline Pink Splash Allusion & Pale green leaves with light pink speckles. \\
\hline Berry Allusion & Starting in the center of the leaves, white fades to green with light red veins. \\
\hline Bold Allusion & Large, cordate leaves are cream-colored with splashes of olive at the margins and pink veins. \\
\hline Confetti & Light green leaves have large, pink splotches and pink-white veins. \\
\hline Glo-Go & Compact with limited vining; leaves are dark green with striking, light cream-colored veins. \\
\hline Infra-Red & Young solid pink leaves mature into solid green. \\
\hline Key Lime & Bright green leaves with bold, white veins. \\
\hline Maria Allusion & Compact; leaves are dark green with a red-bronze tint and dark pink veins. \\
\hline Bob Allusion & $\begin{array}{l}\text { Compact; very similar to Bold Allusion except the olive coloring extends beyond the margins to } \\
\text { the interior of the leaf blade. }\end{array}$ \\
\hline Cream Allusion & Leaves are almost solid cream with bright pink veins and thin, dark leaf margins. \\
\hline Emerald Gem & Solid green with undulating, glossy leaf blades. \\
\hline Holly M & Compact; leaves are nearly solid white with small, dark, green speckles on the margins. \\
\hline Lemon Lime & $\begin{array}{l}\text { Cream-colored veins meet an interior margin of the same shade. The rest of the leaf is } \\
\text { medium green. }\end{array}$ \\
\hline Neon & Solid, bright pink leaves. \\
\hline Pink Allusion & Light, olive-green leaves with deep pink veins. \\
\hline Pixie & Compact; white radiates from the leaf veins abruptly into dark green. \\
\hline Regina Red & Blushing red leaves with olive-green speckles on the margins. \\
\hline Robusta & Broad, green leaves with white veins; reluctant to vine. \\
\hline White Butterfly & $\begin{array}{l}\text { Mostly white-yellow veins bordered with dark green. Considered to be the standard } \\
\text { Syngonium. }\end{array}$ \\
\hline
\end{tabular}

Table 2. Nutrient concentrations in leaves considered low, medium, and high for Syngonium growth.

\begin{tabular}{|c|c|c|c|}
\hline Nutrient & Low & Medium & High \\
\hline Nitrogen & less than $2.5 \%$ & $2.5-4.0 \%$ & greater than $4.0 \%$ \\
\hline Phosphorus & less than $0.2 \%$ & $0.2-0.8 \%$ & greater than $0.8 \%$ \\
\hline Potassium & less than $2.0 \%$ & $2.0-6.0 \%$ & greater than $6.0 \%$ \\
\hline Calcium & less than $1.0 \%$ & $1.0-2.0 \%$ & greater than $2.0 \%$ \\
\hline Magnesium & less than $0.3 \%$ & $0.3-0.8 \%$ & greater than $0.8 \%$ \\
\hline Sulfur & less than $0.2 \%$ & $0.2-0.5 \%$ & greater than $0.5 \%$ \\
\hline Iron & less than $50 \mathrm{ppm}$ & $50-300$ ppm & greater than $300 \mathrm{ppm}$ \\
\hline Manganese & less than 50 ppm & 50 - 300 ppm & greater than 300 ppm \\
\hline Zinc & less than $25 \mathrm{ppm}$ & $25-150$ ppm & greater than $150 \mathrm{ppm}$ \\
\hline Copper & less than $10 \mathrm{ppm}$ & $10-50$ ppm & greater than 50 ppm \\
\hline Boron & less than 25 ppm & $25-50$ ppm & greater than 50 ppm \\
\hline
\end{tabular}


Table 3. Causes and effects of various physiological problems.

\begin{tabular}{|c|c|c|}
\hline Symptoms & Probable Cause & Treatment \\
\hline $\begin{array}{l}\text { Plants are stretched with elongated } \\
\text { internodes and weak. }\end{array}$ & Low light level. & Increase light levels to $2500 \mathrm{fc}$. \\
\hline $\begin{array}{l}\text { Portions of leaves or entire young } \\
\text { leaves appear wet or water-soaked. }\end{array}$ & $\begin{array}{l}\text { Water imbalance in plants (leaf } \\
\text { tissue is warm but medium is still } \\
\text { cold). }\end{array}$ & $\begin{array}{l}\text { Maintain root temperature at } 65^{\circ} \mathrm{F} \text { or } \\
\text { higher and increase air temperature slowly. }\end{array}$ \\
\hline Old leaves tend to turn yellow. & $\mathrm{N}$ deficiency or media run to dry. & $\begin{array}{l}\text { Apply } \mathrm{N} \text { at } 150 \mathrm{ppm} \text { weekly or maintain } \\
\text { media moisture. }\end{array}$ \\
\hline $\begin{array}{l}\text { Water-soaked, irregularly shaped } \\
\text { spots with their centers fallen. }\end{array}$ & Cold water damage in the winter. & $\begin{array}{l}\text { Irrigate plants with water at the same } \\
\text { temperature as the air. Reduce water } \\
\text { condensation in greenhouses. }\end{array}$ \\
\hline $\begin{array}{l}\text { Reduced growth and necrotic spots } \\
\text { on lower leaves. }\end{array}$ & Phosphorus deficiency. & $\begin{array}{l}\text { Apply } \mathrm{P} \text { into media by supplying a fertilizer } \\
\text { with a 3-1-2 (N-P O }-\mathrm{K} O) \text { ratio. }\end{array}$ \\
\hline
\end{tabular}

